\title{
PERANAN PEMERINTAH DAERAH DALAM MEMFASILITASI KETENAGAKERJAAN UNTUK MENINGKATKAN INVESTASI PUBLIK DI KABUPATEN MELAWI, PROVINSI KALIMANTAN BARAT
}

\author{
P. R. Benirobin ${ }^{1}$, Muchlis Hamdi ${ }^{2}$, Rossy Lambelanova ${ }^{3}$, Reydonnizar Moenek $^{4}$ \\ ${ }_{1,2,3,4}$ Institut Pemerintahan Dalam Negeri (IPDN) \\ Email: benirobinaker@yahoo.com
}

\begin{abstract}
Abstrak
Tujuan penelitian adalah untuk memperoleh gambaran belum optimalnya peranan Pemerintah Daerah Kabupaten Melawi dalam memfasilitasi ketenagakerjaan untuk meningkatkan investasi publik di Kabupaten Melawi. Metode penelitian adalah kualitatif dengan melakukan wawancara, observasi dan dokumentasi. Peneliti melakukan analisis dengan berpedoman pada lingkup fasilitasi ketenagakerjaan yang terdapat pada Undang-Undang Nomor 13 Tahun 2003 yaitu fasilitasi pelatihan kerja, fasilitasi penempatan tenaga kerja dan perluasan kesempatan kerja serta fasilitasi hubungan industrial; dan menggunakan teori peranan dari Siagian yang menyatakan bahwa peranan pemerintah adalah sebagai stabilisator, inovator, modernisator, pelopor dan pelaksana.
\end{abstract}

Kata Kunci: Pemerintah Daerah, Ketenagakerjaan, Investasi Publik.

\begin{abstract}
The research objective is to obtain a picture of the sub-optimal role of the Melawi Regency Government in facilitating employment to increase public investment in Melawi Regency. The research method is qualitative with interviews, observation and documentation. The researcher conducted an analysis guided by the scope of facilitating manpower contained in Law Number 13 of 2003, namely facilitating job training, facilitating employment placement and expanding job opportunities and facilitating industrial relations; and using Siagian's role theory which states that the role of government is as a stabilizer, innovator, modernizer, pioneer and implementer.
\end{abstract}

Keywords: Local Government, Employment, Public Investment.

\section{A. PENDAHULUAN}

Berdasarkan pandangan teori politik Anglo-Amerika, konsep pemerintahan merujuk pada institusi formal negara (dan turunannya) serta bagaimana kemampuan mereka untuk memaksa secara legal (yang cenderung dimonopoli). Maka, pemerintah sebagai institutsi formal negara, dimaknai secara umum dengan kemampuannya untuk memaksa. Adapun secara lebih khusus, pemerintah dimaknai dengan merujuk pada proses formal dan institusional yang bekerja pada level negara untuk mempertahankan kekuasaan publik dan memfasilitasi aksi-aksi kolektif (Stoker, 1998). 
Adapun, salah satu bentuk fasilitasi tersebut, yang juga merupakan peranan utama dari pemerintahan (atau institusi pemerintah) adalah memberikan arah terhadap jalannya pemerintahan. Arah tersebut tentunya mampu dijalankan dengan baik apabila terdapatnya perencanaan benar. Salah satu bentuk perencanaan tersebut tertuang secara konkrit dalam konsep pembangunan yang direncanakan dan dieksekusi oleh pemerintah, baik pusat maupun daerah

Tentunya dibutuhkan dana untuk melaksanakan suatu proses pembangunan, baik itu fisik, maupun non-fisik. Konsep pembiayaan tersebutlah yang kemudian disebut sebagai investasi. Jenis dari investasi itu sendiri secara sederhana dapat dibagi menjadi dua, yaitu sumber dana investasi dan sektor tujuan dari investasi itu sendiri. United Nation (2009), menegaskan bahwa keduanya dibagi berdasarkan aspek publik dan privat/swasta. Oleh karenanya istilah investasi itu sendiri terbagi kedalam investasi publik dan investasi privat/swasta.

Merujuk pada dua jenis investasi tersebut, investasi publik merupakan sumber utama investasi, khususnya bagi negara berkembang. Hal tersebut ditekankan (Pritchett, 2000) dalam penelitiannya, bahwa aspek penting yang juga menjadi hal utama dalam investasi publik adalah besaran biaya yang dikeluarkan dibandingkan nilai yang didapat dari investasi yang diutamakan dalam riset empiris, dimana hal tersebut akan lebih kompleks dalam investasi swasta.

Sedangkan jika ditinjau dari jenis investasi antara fisik dan non-fisik, jenis investasi fisik tidak jauh lebih utama dari investasi non-fisik. Walaupun investasi fisik terlihat secara konkrit, namun dampak dari investasi non-fisik memiliki dampak yang lebih mendasar, bertahan lebih lama, dan khususnya memiliki tingkat eksponensial yang tinggi. Contoh tingkat eksponensial tersebut adalah berbanding lurusnya tingginya tingkat produktifitas dengan sumber daya manusia yang terdidik. Maka sumber daya yang tidak terdidik akan kurang produktif. Weisbord (1962) menegaskah bahwa hal ini tentunya berdampak besar pada pembangunan fisik dan non-fisik yang tidak terlepas juga dengan kemajuan teknologi saat ini.

Salah satu bentuk investasi pada manusia atau sumber daya manusia tersebut diantaranya adalah pendidikan dan pelatihan, disamping aspek kesehatan yang juga dijelaskan oleh Weisbord. Adapun pada penelitian lain sebagaimana disebutkan oleh Psacharopoulos (1994), bahkan pendidikan memiliki manfaat utama dan dampak yang besar sebagi aspek investasi sumber daya manusia. Bahkan keuntungan yang didapat dari investasi pendidikan berlaku secara global dan telah menjadi prioritas dari negara-negara berkembang. 
Untuk di Indonesia sendiri, ide tersebut ditopang dengan beberapa penelitian. Diantaranya pertama, penelitian Byron \& Takahashi (1989) yang menjelaskan bahwa terdapat suatu koefisien antara presentase pendidikan dengan tingkat pemasukan atau penghasilan. Semakin tinggi dan terampil seseorang, semakin besar penghasilan yang didapatkan.

Kedua, penelitian dari Boediono dari Australian National University sebagai penelitian yang menarik, dimana dalam riset tersebut terdapat faktor kebijakan sebagai salah satu dari tiga aspek yang mempengaruhi perekonomian dari aspek pendidikan vokasi dan teknik atau yang beliau singkat menjadi VOTEC (vocational and technical education). Beberapa kebijakan yang berkontribusi positif terhadap perkembangan VOTEC memiliki dampak yang positif, bahkan sebagian cukup signifikan (McMahon, 1992).

Dari tinjauan diatas, dapat dilihat bahwa pendidikan dan pelatihan memiliki peran yang cukup vital bagi perkembangan perekonomian di Indonesia. Aspek tersebut layak menjadi salah satu prioritas investasi publik di Indonesia. Ditambah lagi aspek tersebut memiliki nilai pengembalian investasi yang besar. Oleh karenanya, investasi di bidang pendidikan dan pelatihan bagi sumber daya manusia di Indonesia, perlu mendapatkan perhatian untuk mendapatkan peningkatan pengembalian investasi publik.

Menariknya workforce (dalam istilah ekonomi) atau kekuatan pekerja di Indonesia tidak hanya terkonsentrasi pada kementerian pendidikan. Mereka juga terdistribusi pada peranan kementerian tenaga kerja, khususnya pada aspek manajerial, lebih jauh lagi pada aspek perencanaan dan fasilitasi sepertik pendidikan dan pelatihan, juga aspek kontrol dan pengawasan. Dan hal ini perlu mendapatkan kajian khusus, mengingat semangat Dikti dalam mengembangkan kurikulum pun setidaknya terinpirasi dari Australia. Namun, negara tersebut memfokuskan aspek workforce pada ministry of education saja, sebagaimana dijelaskan oleh Department of Foreign Affairs and Trade (1976).

Oleh karenanya, penelitian ini melakukan penelitian pada aspek fasilitasi ketenagakerjaan sebagai hal yang sangat berkaitan dengan kualitas SDM di Indonesia. Adapun dasar dari fasilitasi tersebut, peneliti berpedoman pada Undang-Undang Nomor 13 Tahun 2003 tentang Ketenagakerjaan, yaitu: fasilitasi pelatihan kerja, fasilitasi penempatan tenaga kerja dan perluasan kesempatan kerja, serta fasilitasi hubungan industrial.

Adapun peneliti mengambil contoh salah satu Dinas Tenaga Kerja di Indonesia. Adapun dalam penelitian ini, penulis mengambil contoh di Indonesia, yakni Dinas Tenaga Kerja di Kabupaten Melawi, Provinsi Kalimantan Barat dengan beberapa alasan lain disamping argumentasi sebelumnya, yaitu: pertama, dikarenakan peneliti bekerja di Dinas tersebut, sehingga diharapkan dapat mendapatkan data dan informasi yang cukup baik dan 
lengkap. Disamping itu, kedua, kondisi pandemi covid-19 ini menyebabkan peneliti perlu melakukan penjagaan jarak secara fisik atau physical distancing, sehingga penelitian pada satu lokus yang sama dengan lokasi kerja akan memudahkan penjagaan jarak tersebut.

Permasalahan yang ingin diangkat oleh peneliti dalam penelitian ini adalah belum optimalnya peranan Pemerintah Daerah Kabupaten Melawi dalam memfasilitasi ketenagakerjaan untuk meningkatkan investasi publik di Kabupaten Melawi sehingga diharapkan dengan adanya penelitian ini dapat didapat gambaran dan dapat memberi masukan kepada pemerintah Kabupaten Melawi dan menjadi dasar pertimbangan dalam meningkatkan kinerjanya.

\section{B. METODE}

Pada penelitian ini, penulis menggunakan desain penelitian kualitatif. Menurut Creswell (2009), penelitian kualitatif merupakan metode untuk mengekplorasi dan memahami makna yang oleh sejumlah individu atau sekelompok orang dianggap berasal dari masalah sosial atau kemanusiaan. Permasalahan yang akan dikaji oleh peneliti merupakan masalah yang bersifat sosial dan dinamis. Oleh karena itu, peneliti memilih menggunakan metode penelitian kualitatif untuk menentukan cara mencari, mengumpulkan, mengolah dan menganalisis data hasil penelitian tersebut.

Penelitian kualitatif adalah penelitian yang menggunakan banyak metode, pendekatan interpretif dan naturalistic, mengamati obyeknya dalam latar alamiah, berusaha untuk memaknai atau menginterpretasikan fenomena dari sudut pandang masyarakatnya melibatkan penggunaan berbagai mater empiris yang diperoleh dari studi kasus, pengalaman pribadi, introspeksi, cerita kehidupan, interview, observasi, sejarah, interaksional, dan teks-teks visual, yang dapat menggambarkan momen dan makna yang rutin dan problematik dalam kehidupan individu (Denzin \& Lincoln, 1998).

Dalam penelitian ini digunakan metode kualitatif dengan desain deskriptif, yaitu menganalisis dan menyajikan fakta secara sistematik sehingga dapat lebih mudah dipahami dan disimpulkan. Pendekatan yang digunakan dalam penelitian ini adalah pendekatan kualitatif, penelitian kualitatif tidak menggunakan perhitungan atau diistilahkan dengan penelitian ilmiah yang menekankan pada karakter alamiah sumber data (Azwar, 2002).

\section{HASIL DAN PEMBAHASAN}

Peranan Pemerintah Daerah dalam memfasilitasi ketenagakerjaan untuk meningkatkan investasi publik di Kabupaten Melawi diukur berdasarkan lingkup fasilitasi 
ketenagakerjaan yang terdapat di dalam Undang-Undang Nomor 13 Tahun 2003 tentang Ketenagakerjaan. Adapun lingkup fasilitasi ketenagakerjaan tersebut antara lain: fasilitas pelatihan kerja, fasilitasi penempatan tenaga kerja, dan fasilitasi perluasan kesempatan kerja. Untuk lebih jelasnya dapat dilihat pada uraian di bawah ini:

\section{Peranan Pemerintah Daerah dalam Memfasilitasi Ketenagakerjaan Untuk Meningkatkan Investasi Publik di Kabupaten Melawi}

Pada Pasal 9 diamanatkan bahwa "Pelatihan kerja diselenggarakan dan diarahkan untuk membekali, meningkatkan, dan mengembangkan kompetensi kerja guna meningkatkan kemampuan, produktivitas, dan kesejahteraan." Salah satu penyelenggara pelatihan kerja adalah lembaga pelatihan kerja pemerintah dan/atau lembaga pelatihan kerja swasta. Pada Pasal 15 disebutkan bahwa penyelenggara pelatihan kerja wajib memenuhi persyaratan: tersedianya tenaga kepelatihan; adanya kurikulum yang sesuai dengan tingkat pelatihan; tersedianya sarana dan prasarana pelatihan kerja; dan tersedianya dana bagi kelangsungan kegiatan penyelenggaraan pelatihan kerja.

Program pelatihan kerja perlu dilaksanakan setiap tahunnya dalam rangka memberikan pembinaan bagi calon tenaga kerja karena pelatihan kerja merupakan serangkaian upaya yang dilaksanakan secara bertahap, berkesinambungan, dan terpadu demi mencapai tujuan organisasi. Peran Dinas Tenaga Kerja, Kabupaten Melawi ialah sebagai suatu lembaga pemerintahan yang memberikan pelayanan dalam bidang ketenagakerjaan, dalam rangka mempersiapkan tenaga kerja agar lebih berdaya saing di pasar kerja dan mengupayakan pencari kerja untuk memperoleh pekerjaan yang layak.

Salah satu bentuk pelayanan terhadap tenaga kerja pada saat memasuki persiapan kerja yaitu Dinas Tenaga Kerja, Kabupaten Melawi membekali keterampilan-keterampilan bagi pencari kerja melalui kerjasama yang dilakukan dengan LPK yang ditunjuk. Dalam penyelenggaraan program pelatihan kerja tahun 2017 s/d tahun 2019, Dinas Tenaga Kerja, sebagai pengelola anggaran sekaligus pelaksana kegiatan. Pelaksanaan program pelatihan kerja tahun 2017 dan tahun 2018 lalu pada Dinas tenaga Kerja, merupakan salah satu upaya Pemerintah Daerah Kabupaten Melawi untuk meningkatkan kualitas dan produktivitas tenaga kerja yang diharapkan dapat meningkatkan daya saing dalam memasuki pasar kerja maupun sebagai bekal untuk membuka usaha mandiri (berwirausaha) demi menekan angka pengangguran di Kabupaten Melawi.

Pemerintah Daerah Kabupaten Melawi diwakili oleh Dinas Tenaga Kerja, sebagai kuasa pengguna anggaran, sekaligus sebagai SKPD yang ditunjuk melaksanakan program 
tersebut belum maksimal di jalankan. Hal ini dikarenakan, belum tersedianya Balai Latihan Kerja (BLK) untuk wilayah Kabupaten Melawi sehingga program pelatihan kerja secara langsung ditangani oleh Dinas Tenaga Kerja. Pelaksanaan program pelatihan kerja di Dinas Tenaga Kerja, Kabupaten Melawi ini terdiri dari tiga tahap, yakni perencanaan, pelaksanaan, dan evaluasi.

Peneliti menilai Pemerintah Daerah Kabupaten Melawi memiliki kewenangan yang luas terhadap penyelenggaraan program ini. Pemerintah Daerah berhak berpartisipasi dengan menggunakan sumber daya yang ada untuk merancang dan membangun perekonomian daerah. Para pegawai Dinas Tenaga Kerja, Kabupaten Melawi beserta masyarakat mendapat kesempatan untuk berperan serta dalam perencanaan kegiatan. Peran pegawai sebagai pelaksana adalah menentukan jenis pelatihan kerja yang dibuka dalam program pelatihan kerja. Penentuan tersebut pada mulanya berasal dari analisis kebutuhan pelatihan di wilayah Kabupaten Melawi yang berasal dari masyarakat maupun pasar kerja.

Dengan demikian, penyusunan program terbentuk dari inisiasi masyarakat dan industri yang membutuhkan tenaga kerja. Selain masyarakat, para pegawai juga berhak memberikan keputusan dan mempengaruhi pembuatan kebijakan. Para instruktur memiliki hak untuk menyusun kurikulum yang disesuaikan dengan kondisi dan potensi ketenagakerjaan di Kabupaten Melawi. Aktivitas tersebut bertujuan untuk merancang lingkungan pelatihan kerja dan metode-metode yang diperlukan untuk mencapai tujuan program.

Pelaksanaan program pelatihan kerja di Dinas Tenaga Kerja, Kabupaten Melawi ini terdiri dari tiga tahap, yakni perencanaan, pelaksanaan, dan evaluasi. Tahap perencanaan dimulai dari penyusunan Renja, penyusunan Pra-RKA, penyusunan RKA, turunnya DPA, penetapan DPPKAD dan SK Penyelenggaraan, kemudian dilakukan sosialisasi, diikuti dengan rekruitmen. Tahap kedua adalah pelaksanaaan program pelatihan kerja, kemudian tahap ketiga adalah evaluasi yang dilaksanakan oleh Dinas Tenaga Kerja, Kabupaten Melawi. Dinas Tenaga Kerja, Kabupaten Melawi melaksanakan sosialisasi program guna menarik perhatian para pencari kerja untuk mengikuti program tersebut. Sosialisasi dilakukan melalui berbagai media komunikasi seperti media cetak, media elektronik, dan Musrenbang. Dalam tahap perencanaan dari tahun 2017-2019, tidak terdapat hambatan yang begitu berarti, sehingga dapat dikatakan bahwa proses awal dari pelaksanaan program pelatihan kerja tersebut telah berjalan dengan baik.

Terdapat beberapa aspek penting yang harus diperhatikan dalam penyelenggaaraan program pelatihan kerja tersebut yaitu berupa unsur- unsur pelatihan kerja. Beberapa unsur 
penyelenggaraan pelatihan telah dilaksanakan dan diterapkan dengan baik oleh Dinas Tenaga Kerja, Kabupaten Melawi diantaranya sebagai berikut:

a. Tujuan Pelatihan Kerja

Hal pertama yang harus diperhatikan dalam penyelenggaraan program pelatihan kerja adalah penentuan tujuan. Adanya tujuan membuat kegiatan tersebut menjadi lebih terarah. Tujuan utama program pelatihan kerja ini adalah meningkatkan pengetahuan, keterampilan, dan sikap kerja para peserta sebagai upaya menekan angka pengangguran.

Berdasarkan tujuan secara umum tersebut, maka dapat diketahui bahwa tujuan jangka pendek program pelatihan kerja adalah mempersiapkan calon tenaga kerja untuk meningkatkan daya saingnya dalam memasuki pasar kerja, sedangkan tujuan jangka panjang program pelatihan kerja adalah mengurangi jumlah pengangguran di Kabupaten Melawi. Tujuan pelatihan kerja inilah yang akan menjadi dasar utama penyelenggaraan program, baik untuk mengukur keberhasilan maupun kegagalan program. Dilihat dari penetapan tujuan, maka dapat diketahui keterampilan-keterampilan yang diajarkan pada program pelatihan kerja, kemudian identifikasi terhadap materi yang diberikan selama proses pelatihan kerja berlangsung.

b. Peserta Pelatihan Kerja

Pencari kerja adalah input dalam program pelatihan kerja ini karena merupakan sasaran dari penyelenggaraan program. Peserta merupakan subyek sekaligus obyek yang menentukan keberhasilan pelaksanaan pelatihan kerja. Peserta dituntut untuk memiliki kemauan dan kemampuan dalam mengikuti pelatihan kerja, sehingga mendukung kelancaran kegiatan dan pencapaian tujuan. Mengingat kedudukan peserta yang memiliki peran penting dalam keberhasilan program, maka sesuai dengan teori Hamalik (2005), bahwa kriteria penentuan peserta harus memenuhi persyaratan melalui persyaratan akademik, jabatan, pengalaman kerja, motivasi dan minat, tingkat intelektualitas yang diketahui melalui tes seleksi. Sebelum mengikuti kegiatan pelatihan kerja, peserta harus melalui tahap rekruitmen yang meliputi pendaftaran, seleksi, dan pengumuman hasil seleksi calon peserta. Dari hasil rekruitmen, diperoleh Tahun 2017 berjumlah 240 peserta, Tahun 2018 sebanyak 350 pesrta dan tahun 2019 sebanyak 200 peserta yang siap mengikuti 11 jenis pelatihan kerja pada program pelatihan kerja.

c. Materi Pelatihan Kerja

Materi yang diberikan kepada peserta pelatihan kerja disesuaikan dengan tujuan pelatihan. Tujuan program ini lebih mengacu pada peningkatan keterampilan pencari kerja, sehingga materi yang diberikan lebih banyak bersifat praktek. Pembagian jam pelajaran 
pelaksanaan pelatihan kerja di Dinas Tenaga Kerja, Kabupaten Melawi ialah 25\% teori dan $75 \%$ praktek. Pemberian materi berupa teori diberikan pada awal pelatihan sebagai dasar para peserta untuk menguasai materi dalam praktek pelatihan kerja, baik menguasai pengetahuan umum, alat, maupun bahan yang akan digunakan. Kegiatan praktek memiliki komposisi lebih banyak karena diharapkan peserta memperoleh pengalaman atau keterampilan praktis sehingga siap untuk masuk ke dalam dunia kerja usai pelatihan kerja selesai.

d. Metode Pelatihan Kerja

Metode pelatihan kerja yang digunakan Dinas Tenaga Kerja, Kabupaten Melawi ialah metode yang dilakukan dengan cara peragaan dan penjelasan mengenai cara mengerjakan sesuatu melalui contoh yang didemonstrasikan oleh instruktur. Pelatihan kerja ini lebih menekankan pada peningkatan keterampilan, maka pemberian jam untuk praktek memang dikondisikan lebih banyak daripada jam untuk teori.Instruktur mendemonstrasikan dengan mencontohkan penggunaan peralatan langsung pada bidang kerja yang telah disediakan, kemudian mempersilahkan peserta untuk mengikuti langkah-langkahnya dengan benar.

Untuk mendukung metode ini, maka instruktur akan menyediakan materi dalam bentuk modul, dijelaskan melalui ceramah lisan, kemudian dibuka kesempatan diskusi. Metode ini cukup efektif karena peserta dapat mengamati secara langsung teknik-teknik pengerjaan dan mencatat penjelasan-penjelasan yang dianggap perlu. Salah satu jenis pelatihan kerja yaitu pelatihan montir sepeda motor juga menggunakan metode pemagangan.

Tujuan dari metode ini ialah untuk memberikan kecakapan yang diperlukan sesuai dengan tuntutan kemampuan dari pekerjaan tersebut. Peserta mendapat kesempatan untuk berlatih bekerja di tempat kerja yang telah ditentukan. Pemagangan ini bertujuan agar peserta mengenal secara langsung penerapan keterampilan dalam dunia kerja. Para peserta dapat memahami disiplin kerja, tata cara, penggunaan dan pemeliharaan peralatan kerja, serta manajemen pelayanan bagi konsumen.

\section{e. Media Pelatihan Kerja}

Penggunaan media dalam proses pelatihan kerja merupakan kebutuhan karena banyak materi pelatihan kerja yang memerlukan kesamaan persepsi bagi para peserta, materi juga lebih mudah dipahami apabila dibantu dengan adanya media. Pemilihan dan penggunaaan media telah mempertimbangkan tujuan dan materi pelatihan kerja, ketersediaan media tersebut juga harus disertai dengan kemampuan instruktur untuk menggunakannya. Instruktur menggunakan beberapa media pembelajaran secara bervariasi sebagai alat bantu untuk menyajikan materi agar memudahkan peserta memahami materi yang dijelaskan. 
Dinas Tenaga Kerja, Kabupaten Melawi menggunakan benda-benda asli berupa mesin maupun peralatan pendamping untuk membantu peserta dalam mempraktekkan materi pembelajaran. Selain itu, untuk meminimalisir ruang yang dibutuhkan, digunakan pula media gambar asli untuk menjelaskan informasi dari percontohan materi yang diberikan. Media papan tulis atau white board mendukung metode ceramah.

Media tersebut dapat digunakan untuk menjelaskan materi yang dituliskan atau digambarkan di papan, kemudian dijelaskan secara lisan untuk dipahami peserta. Adapula media cetak, media ini adalah bahan hasil cetakan yang membantu peserta dalam memahami materi pelatihan, seperti modul pelatihan kerja.

Berbagai media pelatihan yang disediakan Dinas Tenaga Kerja, Kabupaten Melawi sangat mendukung keberlangsungan kegiatan. Media pembelajaran tersebut sangat membantu penyelenggaraan program, sehingga diperlukan adanya keberlanjutan dan kesinambungan penggunaan media terhadap perkembangan ilmu pengetahuan dan teknologi.

\section{f. Manfaat Pelatihan Kerja}

Setiap pelaksanaan kegiatan diharapkan dapat memberikan manfaat baik bagi individu maupun bagi organisasi. Dengan adanya manfaat bagi individu menjadikan seseorang termotivasi untuk meningkatkan kualitas dirinya sendiri.penyelenggaraan program ini membawa dampak positif bagi individu sekaligus organisasi. Berdasarkan pengamatan peneliti terhadap beberapa lulusan peserta pelatihan kerja tahun 2017-2019 tersebut, dapat diketahui ada manfaat yang diterima berupa peningkatan pengetahuan dan keterampilan, sikap kerja, dan pengalaman menggunakan mesin maupun peralatan kerja, serta membekali peserta dengan pengalaman kerja sesuai bidang yang dipilihnya sehingga mempermudah peserta untuk mendapatkan pekerjaan. Individu-individu yang merasakan langsung manfaat dari pelatihan kerja ini ialah para peserta pelatihan kerja tahun 2017-2019 tersebut.

Selain unsur-unsur yang mendukung pelaksanaan program, terdapat beberapa unsur yang menghambat atau menjadi kendala bagi keberlangsungan program tersebut. Perubahan selalu terjadi dan tidak dapat diprediksi, pemerintah pasti menghadapi berbagai hambatan yang mengganggu kelancaran penyelenggaraan kegiatannya. Pelaksanaan program pelatihan kerja untuk menekan angka pengangguran di wilayah Kabupaten Melawi tersebut juga tidak terlepas dari kendala yang harus dihadapi oleh pemerintah sebagai penyelenggara program. 


\section{Peranan Pemerintah Derah dalam Memfasilitasi Penempatan Tenaga Kerja dan Perluasan Kesempatan Kerja di Kabupaten Melawi}

Pasal 1 ayat (12) Undang-Undang Nomor 13 Tahun 2003 menyebutkan bahwa: "Pelayanan penempatan tenaga kerja adalah kegiatan untuk mempertemukan tenagakerja dengan pemberi kerja, sehingga tenaga kerja dapat memperoleh pekerjaan yang sesuai dengan bakat, minat, dan kemampuannya, dan pemberi kerja dapat memperoleh tenaga kerja yang sesuai dengan kebutuhannya". Pasal 32 mengamanatkan bahwa: "Penempatan tenaga kerja diarahkan untuk menempatkan tenaga kerja pada jabatan yang tepat sesuai de ngan keahlian, keterampilan, bakat, minat, dan kemampuan dengan memperhatikan harkat, martabat, hak asasi, dan perlindungan hukum." Pada pasal 36 ayat (2) dijelaskan bahwa Pelayanan penempatan tenaga kerja sebagaimana dimaksud dalam ayat (1) bersifat terpadu dalam satu sistem penempatan tenaga kerja yang meliputi unsur-unsur: a. pencari kerja; $b$. lowongan pekerjaan; c. informasi pasar kerja; d. mekanisme antar kerja; e. kelembagaan penempatan tenaga kerja.

Salah satu tujuan dari pembangunan ketenagakerjaan adalah untuk mewujudkan pemerataan kesempatan kerja. Pasal 39 menjelaskan bahwa: "Pemerintah bertanggung jawab mengupayakan perluasan kesempatan kerja baik di dalam maupun di luar hubungan kerja." Penciptaan perluasan kesempatan kerja dilakukan dengan pola: a) pembentukan dan pembinaan tenaga kerja mandiri; b) penerapan sistem padat karya; c) penerapan teknologi tepat guna, dan d) pendayagunaan tenaga kerja sukarela atau e) pola lain yang dapat mendorong terciptanya perluasan kesempatan kerja.

Berdasarkan data yang diperoleh di lapangan, dalam hal fasilitasi penempatan tenaga kerja dan perluasan kesempatan kerja, para pencari kerja difasilitasi dengan pemberian pelayanan kartu pencari kerja, dimana pada tahun 2017 sejumlah 222 orang para pencari kerja, pada tahun 2018 sejumlah 317 orang dan pada tahun 2019 terdapat 136 orang pencari kerja yang menerima pelayanan kartu pencari kerja. Dalam pelaksanaan fasilitasi penempatan kerja dan perluasan kesempatan kerja, Dinas Tenaga Kerja Kabupaten Melawi mengalami beberapa hambatan.

Dalam memberikan pelayanan kartu pencari kerja, terdapat gangguan jaringan internet dan pemadaman listrik PLN secara berkala dan tanpa pemberitahuan sebelumnya sehingga berdampak pada terhambatnya proses penerbitan Ak-1. Selain itu terdapat kurangnya fasilitas ruang tunggu sehingga berdampak pada masyarakat pencari kerja yang harus berdesakan ketika menunggu proses penerbitan kartu pencari kerja tersbeut. Dalam aspek pemberian pelayanan ijin memperkerjakan tenaga asing pun mengalami gangguan 
jaringan internet yang berdampak pada terhambatnya proses verifikasi data Tenaga Kerja Asing (TKA) ke pusat. Selain itu dalam pelaksanaan pelayanan tersebut, belum tersedianya pelatihan bagi petugas penginput sehingga berdampak pada lambatnya proses verifikasi data TKA. Pada pelayanan rekomendasi paspor TKI, terdapat kurangnya kelengkapan berkas calon TKI, yang berdampak pada lambatnya proses verifikasi untuk penerbitan rekomendasi. Selain itu calon TKI rtidak memiliki sertifikat kompetensi sehingga pekerjaan calon TKI di luar negeri menjadi tidak menentu dan tidak jelas arahnya.

Kewajiban Pemerintah Kabupaten adalah menyediakan lapangan kerja yang layak bagi semua warganya. Oleh karena itu melalui kebijakan publik yang terencana dan jelas harus mampu menurunkan angka pengangguran terbuka di lingkup Kabupaten Melawi khususnya. Selain menyediakan lapangan pekerjaan, Pemerintah Kabupaten Melawi semestinya berusaha meningkatkan perlindungan tenaga kerja yang meliputi keselamatan kerja, kesehatan kerja, pengupahan dan jaminan sosial tenaga kerja sesuai peraturan perundangan yang mejadi hak pekerja dari seluruh penduduk usia kerja.

Fenomena Ketenagakerjaan Kabupaten Melawi sedikit berbeda dengan kabupaten lainnya di Provinsi Kalimantan Barat, khususnya dalam hal memfasilitasi ketenagakerjaan yang berorientasi kepada peningkatan Investasi Publik Kabupaten Melawi, karena dimensinya adalah regional maka mobilitas calon pekerja yang tinggi di wilayah ini. Migrasi neto-nya bernilai positif yang mempunyai makna bahwa migrasi masuk lebih banyak dibandingkan dengan migrasi keluar, hal ini bisa dilihat dari pertumbuhan penduduk selama periode sensus yang telah dilaksanakan.

Selain masalah ketanagakerjaan, dalam dimensi ekonomi pada masa dahulu indikator keberhasilan ekonomi selalu saja berorientasi pada keberhasilan menghasilkan pendapatan daerah dan bahkan nasional yang tinggi, sehingga pendekatan yang dilakukan adalah lebih mengarah kepada kegiatan produksi. Namun dimasa selanjutnya sampai sekarang, orientasi pembangunan yang berbasis pada produksi semakin tidak populer, karena seringkali keberhasilan pembangunan dengan indikator tersebut tidak dinikmati oleh penduduk secara keseluruhan. Paradigma baru tentang pembangunan sudah bergeser pada pentingnya pembangunan berdimensi manusia (people centered development).

Peneliti menilai bahwa Pemerintah Kabupaten Melawi belum optimal dalam penyebarluasan lowongan pekerjaan dan informasi pasar kerja. Hal tersebut berdampak pada kurangnya informasi yang diperoleh oleh masyarakat pencari kerja. Sementara kebijakan yang mendukung ketenagakerjaan sudah tertuang dalam Surat Edaran dimana seharusnya masyarakat pencari kerja dapat menindaklanjutinya dengan memperoleh pekerjaan sesuai 
dengan keterampilan yang dimiliki sehingga angka pengangguran di Kabupaten Melawi dapat berkurang.

\section{Peranan Pemerintah Derah dalam Memfasilitasi Hubungan Industrial di Kabupaten Melawi}

Pasal 102 Undang-Undang Nomor 13 Tahun 2003 menyebutkan bahwa: "Dalam melaksanakan hubungan industrial, pemerintah mempunyai fungsi menetapkan kebijakan, memberikan pelayanan, melaksanakan pengawasan, dan melakukan penindakan terhadap pelanggaran peraturan perundang-undangan ketenagakerjaan."

Pasal 1 ayat (22) mengamanatkan bahwa: "Perselisihan hubungan industrial adalah perbedaan pendapat yang mengakibatkan pertentangan antara pengusaha atau gabungan pengusaha dengan pekerja/buruh atau serikat pekerja/serikat buruh karena adanya perselisihan mengenai hak, perselisihan kepentingan, dan perselisihan pemutusan hubungan kerja serta perselisihan antar serikat pekerja/serikat buruh hanya dalam satu perusahaan.

Mediator Penyelesaian Perselisihan Hubungan Industrial di Dinas Tenaga Kerja Kabupaten Melawi yang berdampak pada Setiap penyelesaian Perselisihan Hubungan Industrial yang dilaksanakan oleh Dinas Tenaga Kerja Kabupaten Melawi apa bila tidak ada kesepakatan antara pihak yang berselisih maka akan di serahkan penyelesaiannya kepada Mediator Tingkat Provinsi dan akan Memakan biaya bagi pihak yang berselisih; (2) Kurangnya Dukungan Anggaran untuk kegiatan ini yang berdampak pada Setiap penyelesaian Perselisihan Hubungan Industrial yang dilaksanakan oleh Dinas Tenaga Kerja Kabupaten Melawi selalu dilaksanakan di Kantor Dinas Tenaga Kerja Kabupaten Melawi tidak bisa dilaksanakan di Perusahaan tempat perselisihan terjadi.

Berdasarkan uraian data hasil penelitian pada table di atas bahwa keputusan yang dibuat oleh pemerintah belum menjawabi tantangan pasar modal/lembaga keuangan, lebih dari itu masih kurangnya tenaga ahli yang mampu mengelolah berbagai perjanjian dan kontrak yang cukup kompleks, Kurang efisiennya manajemen proses dan investasi yang berujung pada pemberhentian proyek dan outcome yang kurang maksimal bahkan Manajemen resiko yang kurang tepat berdampak pada gagalnya proyek sehingga segera dibuat Project Preparation yang lebih baik dan Project Selection Criteria yang solid dan Perbaikan tata kelola dan pengelolaan risiko yang lebih baik.

Dinas tenaga kerja daerah yang merupakan pelaksana fungsi inti (operating core) yang melaksanakan tugas dan fungsi sebagai pembantu kepala daerah dalam melaksanakan fungsi mengatur dan mengurus sesuai bidang urusan pemerintahan yang diserahkan kepada 
daerah, baik urusan wajib maupun urusan pilihan dan melaksanakan fungsi penunjang (technostructure) yang melaksanakan tugas dan fungsi sebagai pembantu kepala daerah dalam pelaksanaan fungsi mengatur dan mengurus untuk menunjang kelancaran pelaksanaan fungsi inti (operating core). Dalam implementasi otonomi daerah dapat dilakukan penetapan kebijakan penyusunan organisasi perangkat daerah dan struktur organisasi dan tata kerja perangkat tersebut demi mewujudkan pencapaian tujuan otonomi daerah.

Menurut Werf yang dimaksud kebijakan adalah usaha mencapai tujuan tertentu dengan sasaran tertentu dan dalam urutan tertentu. Sedangkan kebijakan pemerintah mempunyai pengertian baku yaitu suatu keputusan yang dibuat secara sistematik oleh pemerintah dengan maksud dan tujuan tertentu yang menyangkut kepentingan umum.

Sesuai dengan sistem administrasi Negara Republik Indonesia, kebijakan dapat dibagi menjadi 2 (dua), yaitu: Kebijakan Internal (Manajerial), yaitu kebijakan yang mempunyai kekuatan mengikat aparatur dalam organisasi pemerintah sendiri, dan Kebijakan eksternal (Publik), yaitu suatu kebijakan yang mengikat masyarakat umum, sehingga dengan kebijakan demikian kebijakan harus tertulis. Pengertian kebijakan pemerintah sama dengan kebijaksanaan berbagai bentuk seperti misalnya jika dilakukan oleh Pemerintah Pusat berupa Peraturan Pemerintah (PP), Keputusan Menteri (KepMen) dan lain lain. Sedangkan jika kebijakan pemerintah tersebut dibuat oleh pemerintah daerah akan melahirkan Surat keputusan (SK), peraturan daerah (PerDa) dan lain lain dapat terwujud.

Setelah menguraikan peranan pemerintah daerah dalam fasilitasi pelatihan kerja, fasilitasi dalam penempatan tenaga kerja dan perluasan kesempatan kerja serta fasilitasi dalam hubungan industrial, peneliti melakukan analisis mengapa peranan pemerintah daerah dalam memfasilitasi ketenagakerjaan untuk meningkatkan investasi publik di Kabupaten Melawi belum optimal, dengan memperhatikan aspek pada masing-masing lungkup fasilitasi tersebut:

a. Faktor Dana

Faktor kurangnya anggaran menjadi faktor penghambat pada lingkup fasilitasi pelatihan kerja dimana dalam anggaran sarana dan prasarana baik tempat penyelenggara pelatihan kerja yaitu Balai Latihan Kerja (BLK) yang belum dimiliki oleh Kabupaten Melawi, sehingga berdampak pada penyelenggaraan pelatihan kerja dilaksanakan di Dinas Tenaga Kerja Kabupaten Melawi. Idealnya, Kabupaten Melawi memiliki tempat pelatihan kerja sendiri sebagai tempat pelaksanaan kegiatan pelatihan kerja yang diselenggarakan oleh Dinas Tenaga Kerja. Selain itu, beberapa peralatan dalam pelaksanaan kegiatan pelatihan kerja mengalami kerusakan sehingga menghambar proses kegiatan pelatihan kerja yang 
sedang berlangsung. Faktor anggaran juga menjadi penghambat dalam rangka pelaksanaan sosialisasi pada pelayanan fasilitasi ijin lembaga pelatihan sehingga berdampak pada tidak tercapainya pendataan Lembaga Pelatihan secara menyeluruh ke seluruh Kecamatan di Kabupaten Melawi. Kurangnya anggaran juga terdapat dalam fasilitasi penyelesaian perselisihan hubungan industrial yang berdampak pada setiap penyelesaian Perselisihan Hubungan Industrial yang dilaksanakan oleh Dinas Tenaga Kerja Kabupaten Melawi selalu dilaksanakan di Kantor Dinas Tenaga Kerja Kabupaten Melawi tidak bisa dilaksanakan di Perusahaan tempat perselisihan terjadi.

b. Faktor Prasarana dan Sarana

Berdasarkan uraian di atas diperoleh informasi bahwa hingga saat penelitian ini dilakukan, Pemerintah Kabupaten Melawi belum memiliki Balai Latihan Kerja yang dapat digunakan sebagai tempat penyelenggara kegiatan pelatihan kerja bagi para calon tenaga kerja. Selain itu, fasilitas seperti mesin dan peralatan yang digunakan selama kegiatan pelatihan kerja berlangsung belum memadai dari segi kualitas. Dalam pelaksanaan fasilitasi terkait pelayanan penempatan tenaga kerja dan perluasan kesempatan kerja pun masih terdapat gangguan jaringan internet dan listrik padam secara berkala tanpa pemberitahuan terlebih dahulu sehingga berdampak pada terhambatnya proses pelayanan. Fasilitas yang dimiliki oleh Dinas Tenaga Kerja, seperti ruang tunggu pun masih kurang memadai dari aspek kuantitasnya.

c. Faktor Informasi

Faktor kurangnya penyebarluasan informasi dirasakan oleh masyarakat pencari kerja di Kabupaten Melawi. Informasi merupakan salah satu aspek yang dibutuhkan oleh masyarakat pencari kerja. Informasi pasar kerja merupakan salah satu aspek pada fasilitasi penempatan tenaga kerja. Sebagaimana uraian sebelumnya, bahwa masih terdapat masyarakat pencari kerja yang belum mengetahui informasi lowongan pekerjaan dan informasi pasar kerja. Hal ini perlu diperhatikan oleh Dinas Tenaga Kerja agar dapat melaksanakan sosialisasi secara menyeluruh dan menyentuh seluruh lapisan masyarakat.

Menurut Charles R. Wright (2010), sosialisasi merupakan suatu proses disaat individu memperoleh kebudayaan dari kelompoknya yang kemudian dilakukan proses internalisasi hingga tingkat tertentu terhadap norma sosialnya, yang selanjutnya memberi bimbingan pada orang tersebut dalam rangka memperhitungkan harapan orang lain. Dengan demikian, peneliti menyimpulkan bahwa dalam sosialisasi terdapat proses interaksi antara orang yang menyampaikan informasi dengan orang yang menerima informasi tersebut. Dalam melaksanakan sosialisasi, diperlukan pola yang tepat agar informasi yang disampaikan dapat 
tepat sasaran. Pola sosialisasi memuat sarana dalam bersosialisasi, yaitu: metode periklanan, metode promosi, dan metode publisitas.

d. Faktor Sumber Daya Manusia (SDM)

Faktor kurangnya sumber daya manusia terdapat pada lingkup fasilitasi pelatihan kerja yakni kurangnya jumlah tenaga kepelatihan (instruktur) sesuai kebutuhan calon pencari kerja. Salah satu faktor penyebabnya adalah karena belum adanya pegawai fungsional yang disediakan sebagai instruktur pelatihan kerja. Selain itu pada lingkup fasilitasi penempatan kerja dan perluasan kesempatan kerja dimana pada pelayanan fasilitasi ijin memperkerjakan tenaga asing, belum ada pelatihan bagi petugas penginput yang memberikan dampak buruk pada lambatnya proses verifikasi data Tenaga Kerja Asing (TKA). Selain itu, pada lingkup fasilitasi hubungan industrial juga belum terdapat pegawai teknis mediator penyelesaian perselisihan hubungan industrial di Dinas Tenaga Kerja Kabupaten Melawi yang berdampak pada setiap penyelesaian perselisihan hubungan industrial yang dilaksanakan oleh Dinas Tenaga Kerja Kabupaten Melawi apa bila tidak ada kesepakatan antara pihak yang berselisih maka akan di serahkan penyelesaiannya kepada Mediator Tingkat Provinsi dan akan Memakan biaya bagi pihak yang berselisih.

Dengan demikian, perlu peran aktif agar tujuan yang disampaikan melalui visi dan misi lembaga pemerintahan ini dapat memberikan sumbagsih yang berarti dalam pengembangan ketenagakerjaan di Kabupaten Melawi, khususnya dalam memberdayakan masyarakat lokal Kabupaten Melawi. Pemerintah daerah sesungguhnya memainkan peranan yang dominan dalam proses pembangunan. Peran yang disoroti adalah selaku stabilisator, innovator, modernisator, pelopor, dan pelaksana suatu kegiatan pembangunan tertentu.

\section{KESIMPULAN}

Peranan pemerintah daerah dalam memfasilitasi ketenagakerjaan di Kabupaten Melawi terdiri atas fasilitasi pelatihan kerja, fasilitasi penempatan tenaga kerja dan perluasan kesempatan kerja dan fasilitasi hubungan industrial. Peranan pemerintah daerah dalam memfasilitasi ketenagakerjaan dalam rangka meningkatkan investasi publik di Kabupaten Melawi belum optimal, disebabkan oleh faktor dana, faktor prasarana dan sarana, faktor informasi dan faktor sumber daya manusia. 


\section{DAFTAR PUSTAKA}

Ary, D. (2002). Introduction to Research in Education. Belmont: Wadaworth Thomson Learning.

Azwar, S. (2002). Metode Penelitian. Yogyakarta: Pustaka Pelajar Offset.

Behrman, J. R. (2010). Investment in education-inputs and incentives. Handbook of Development Economics.

Berry, D. (2003). Pokok-pokok Pikiran dalam Sosiologi. Jakarta: Raja Grafindo Persada.

Byron, R. P. (1989). An analysis of the effect of schooling, experience and sex on earnings iAn anlaysis of the effect of schooling, experience and sex on earnings in the government and private sectors of urban java. Bulletin of Indonesian Economic Studies.

Byron, R. P. (1989). An analysis of the effect of schooling, experience and sex on earnings in the government and private sectors of urban java. Bulletin of Indonesian Economic Studies.

Creswell., J. W. (2016). Penelitian Kualitatif dan Desain Riset, Edisi Indonesia. Yogyakarta: Pustaka Pelajar.

Dabla-Norris, E. B. (2012). Investing in public investment: An index of public investment efficiency. Journal of Economic Growth. Journal of Economic Growth.

Department of Foreign Affairs and Trade. (1976). Australia in Brief. Canberra, Australian Capital Territory: Australian Government.

Dinas Tenaga Kerja. (2018). LAKIP Dinas Tenaga Kerja. Kabupaten Melawi: Pemerintah Kabupaten Melawi.

Dinas Tenaga Kerja. (2019). LAKIP Dinas Tenaga Kerja. Kabupaten Melawi: Pemerintah Kabupaten Melawi.

Halim, A. (2003). Analisis Investasi. Jakarta: Salemba Empat.

Hamalik, O. (2005). Kurikulum dan Pembelajaran. Jakarta. Jakarta: Bumi Aksara.

Hanim, A. D. (2010). Analisis Faktor-Faktor yang Mempengaruhi Minat Investasi di Daerah: Study Kasus di Kabupaten Jember Jawa Timur. Jurnal Kajian Ekonomi dan Keuangan, 14(3).

Hatch, J. (2002). Doing Qualitative Research in Education Settings. Albany: SUNY Press.

Hellen, S. M. (2017). Pengaruh Investasi dan Tenaga Kerja Serta Pengeluaran Pemerintah Terhadap Pertumbuhan Ekonomi Serta Kesempatan Kerja. INOVASI, 13(1), 28-38.

Jacobs, R. L. (2011). Developing a Research Problem and Purpose Statement. Dalam T. S. Hatcher, The Handbook of Scholarly Writing and Publishing, (hal. 125-141). San Francisco: T. S. Rocco and T. Hatcher.

Kuntoro, A. B. (2017). Analisis Ketenagakerjaan Di Provinsi Jawa TimuR. Jurnal Biometrika dan Kependudukan, 6(1).

Kusuma, T. O. (2015). Peran Pemerintah Kabupaten Malang Dalam Meningkatkan Pembangunan Ekonomi Daerah Melalui Sektor Pariwisata. JKMP, 3(1), 1-116.

Lincoln, N. K. (t.t.). Handhbook of Qualitative Research. London-New Delhi: Sage Publication.

Lubis, C. A. (2014). Pengaruh Jumlah Tenaga Kerja, Tingkat Pendidikan Pekerja Dan Pengeluaran Pendidikan Terhadap Pertumbuhan Ekonomi. Jurnal Economia, 10(2).

McMahon, W. W. (1992). Universal basic education: An overall strategy of investment priorities for economic growth. Economics of Education Review, 11(2), 137-151.

Miles, D. (2017). A Taxonomy of Research Gaps: Identifying and Defining the Seven Research Gaps.

Miles, M. B. (1992). Analisis Data Kualitatif. Jakarta: Universitas Indonesia. 
Moleong, L. J. (2010). Metode Penelitian Kualitatif. Bandung: Remaja Rosdakarya.

Müller-Bloch, C. \&. (2014). A Framework for Rigorously Identifying Research Gaps. The Thirty Sixth International Conference on Information Systems, (hal. 1-19). Fort Worth.

Mulyadi. (2001). Akuntansi manajemen, Konsep, Manfaat, dan Rekayasa. Yogyakarta: Universitas Gadjah Mada.

Pasolong, H. (2013). Metode Penelitian Administrasi Publik. Bandung: CV. Alfabeta.

Peraturan Daerah Nomor 32 Tahun 2007 Tentang Pembentukan Kecamatan Pinoh Utara Kecamatan Pinoh Selatan, Kecamatan Belimbing Hulu dan Kecamatan Tanah Pinoh Barat.

Phelps, E. S. (1980). Investment In Humans, Technological Diffusion, And Economic Growth. In Studies in Macroeconomic Theory.

Pritchett, L. (. (2000). The tyranny of concepts: CUDIE (cumulated, depreciated, investment effort) is not capital. Journal of Economic Growth, 361-384.

Psacharopoulos, G. (1994). Returns to investment in education: A global update. World Development, 1325-1343.

Rangkuti, F. (2015). Analisis SWOT Teknik Membedah Kasus Bisnis. Jakarta: Gramedia Pustaka Utama.

Ratna Wardhani, H. R. (2017). Good governance and the impact of government spending on performance of local government in Indonesia. International Journal of Public Sector Performance Management, 3(1).

Rhodes, R. (1996). The New Governance: Governing without Government. Political Studies, $44,652-67$.

Rivai, V. (2004). Manajemen Sumber Daya Manusia Untuk Perusahaan. Jakarta: RajaGrafindo Persada.

Rogers, E. M. (1962). Diffusion of Innovations. Free Press.

Romi Juliansyah, N. d. (2018). The Influence Of Investments, Government Expenditure And Labors On Economic Growth In Aceh Province. Jurnal Ekonomi dan Kebijakan Publik Indonesia, 5(2).

Sartika, A. W. (2019). The effects of investment and government expenditures. International Journal of scientific \& engineering research, 10(7).

Sefle, A. N. B. (2014). Analisis Faktor-Faktor Yang Mempengaruhi Investasi di Kabupaten Sorong (Studi Pada Kabupaten Sorong Tahun 2008-2012). Jurnal Berkala Ilmiah Efisiensi, 14(3).

Siagian, S. P. (2002). Manajemen Sumber Daya Manusia. Jakarta: Bumi Aksara.

Siagian, S. P. (2005). Administrasi Pembangunan, konsep dimensi dan strateginya. Jakarta: Bumi Aksara.

Silalahi, U. (2010). Metode Penelitian Sosial. Bandung: Refika Aditama.

Simangunsong, S. W. (2015). Metodologi Ilmu Pemerintahan. Jatinangor: IPDN Press.

Sitepu, N. (2005). Prinsip-Prinsip Pemasaran Jasa: Teori dan Praktik. Jakarta: Salemba Empat.

Soekanto, S. (2012). Sosiologi Suatu Pengantar. Jakarta: Rajawali Pers.

Subagyo, J. (2011). Metode Penelitian dalam Teori dan Praktik. Jakarta: Rineka Cipta.

Subri, M. (2003). Ekonomi Sumber Daya Manusia. Jakarta: Grafindo.

Sugiama, G. (2014). Metode Riset Bisnis dan Manajemen. Bandung: Penerbit Guardaya Intimarta.

Sugiyono. (2012.). Metode Penelitian Kuantitatif dan R\&D. Bandung: Alfabeta Aksara.

Sugiyono. (2017). Metode Penelitian Kombinasi (Mixed Methods). Bandung: Alfabeta.

Sukirno, S. (2006). Makroekonomi: Teori Pengantar (edisi ke tiga). Jakarta: Rajawali Press. 
Sumarsono, S. (2009). Ekonomi Sumber Daya Manusia Teori dan Kebijakan Publik. . Yogyakarta: Graha Ilmu.

Surat Menteri Dalam Negeri Nomor 135/1213/SJ Tahun 2004 Tentang Perihal Pedoman Teknis Pelaksanaan 13 (tiga belas) Undang-undang tentang Pembentukan 24 (dua puluh empat) Kabupaten.

Suryaningrat, B. (1992). Pemerintahan Administrasi Desa dan Kelurahan. Jakarta: Rineka Cipta.

Suryosubroto. (2010). Dasar-Dasar Kependidikan. Jakarta: Rineka Cipta.

Tandelilin, E. (2001). Analisis Investasi dan Manajemen Portofolio. Yogyakarta: BPFE.

Thoha, M. (2012). Kepemimpinan Dalam Manajemen. Jakarta: PT.Raja Grafindo Persada,.

Undang-Undang Republik Indonesia Nomor 34 Tahun 2003. (2003). Pembentukan Kabupaten Melawi dan Kabupaten Sekadau di Provinsi Kalimantan Barat.

United Nations. (2009). The role of public investment in social and economic development. New York and Geneva: United Nations.

Weisbrod, B. A. (1962 ). Education and Investment in Human Capital. Journal of Political Economy. doi:https://doi.org/10.1086/258728

Werf, H. (1997). Ilmu Manajemen Pemerintahan. Jakarta.

Yin, R. K. (2011). Qualitative Research from start to finish. New York: The Guilford Press. 